\title{
CARBONATION OF MINERALS AND SLAGS UNDER HIGH PRESSURE IN AN AUTOCLAVE
}

\author{
Carlos F. Matus ${ }^{a}$, Srećko R. Stopić ${ }^{b}$, Bernd G. Friedrich ${ }^{c}$ \\ ${ }^{a}$ Refratechnik Cement $\mathrm{GmbH}$, \\ Göttingen, Federal Republic of Germany, \\ e-mail: carlos.matus@refra.com, \\ ORCID ID: (iohttps://orcid.org/0000-0002-3474-5989 \\ ${ }^{b}$ RWTH Aachen University, IME Process Metallurgy and Metal \\ Recycling, Aachen, Federal Republic of Germany, \\ e-mail: sstopic@ime-aachen.de, corresponding author, \\ ORCID iD: (i)https://orcid.org/0000-0002-1752-5378 \\ ${ }^{\mathrm{c}}$ RWTH Aachen University, IME Process Metallurgy and Metal \\ Recycling, Aachen, Federal Republic of Germany, \\ e-mail: bfriedrich@ime-aachen.de, \\ ORCID iD: (1)https://orcid.org/0000-0002-2934-2034
}

DOI: 10.5937/vojtehg69-30203; https://doi.org/10.5937/vojtehg69-30203

\author{
FIELD: Chemical technology \\ ARTICLE TYPE: Original scientific paper
}

\begin{abstract}
:
Introduction/purpose: Carbonation of minerals (olivine and wollastonite) and secondary materials such as slag under high pressure in autoclaves has high importance due to environmetal problems.

Methods: The most important for this process is to have a good knowledge of the behavior of carbon dioxide in water solution under high pressure, the precipitation of silica, dissolution of metals such as nickel and magnesium as well as subsequent filtration.

Results: The carbonation process of olivine und slag under high pressure (from 40 to $80 \mathrm{bar}$ ) in an autoclave was successfully performed at $175^{\circ} \mathrm{C}$, with and without additivies.

Conclusion: A comparative analysis has confirmed better carbonation of slag (max. $300 \mathrm{~kg} / \mathrm{ton}$ ) in comparison to that of olivine (max. $70 \mathrm{~kg} / \mathrm{ton}$ ) under the same conditions.
\end{abstract}

Key words: carbonation, olivine, slag, autoclave, additives.

ACKNOWLEDGMENT: This research was funded by BMBF (Federal Ministry of Education and Research) in Berlin, grant number 033RCO14B (CO2MIN Project in period from 01.06.2017 to 31.12.2020). 


\section{Introduction}

Carbon dioxide has the fourth highest presence in Earth's atmosphere after nitrogen, oxygen and argon and plays a significant role in global warming due to the greenhouse effect. Because of the significant increase of $\mathrm{CO}_{2}$ emissions, carbonation is a promising process in which carbon oxide reacts with compounds with high metal oxide compositions to form chemically stable and insoluble metal carbonates. The choice of experimental parameters (temperature, pressure, solid/liquid ratio, mixing rate, time) for carbonation in an autoclave is of high importance. Although it is reported in literature (Gadikota et al, 2014, pp.4679-4693) that a higher temperature favors mineral dissolution and carbonation, there exists an optimum level of a temperature range. The carbon dioxide solubility is reduced if the temperature is too high. On the other hand, low temperature slows mineral dissolution. The authors suggested that higher conversion was achieved with higher temperature but with a limit to $185^{\circ} \mathrm{C}$. They performed an olivine experiment with varied temperatures at partial pressure of 141 bar, for 3 hours with an additive of $1.0 \mathrm{M} \mathrm{NaCl}+0.64$ $\mathrm{NaHCO}_{3}$ with $15 \mathrm{wt} \%$ solid, and at a stirring speed of $800 \mathrm{rpm}$. The final carbonation rates at $90,125,150$, and $185^{\circ} \mathrm{C}$ were found to be $3.0,28.2$, 70.5 and $85.3 \%$, rspectively. An increase in reaction time from 3 hours to 5 hours does not influence the carbonation efficiency.

The slag carbonation between $40^{\circ} \mathrm{C}$ to $160^{\circ} \mathrm{C}$ with partial pressure set at 48 bar and a reaction time of 1 hour (Chang et al, 2011) confirmed that conversion increased with increasing temperature because of a higher carbonation rate of calcium at higher temperatures. In this experiment, blended hydraulic cement BHC slag showed a more unique route because this conversion decreased after the temperature had exceeded $100^{\circ} \mathrm{C}$. It could be caused by the reduction of carbon dioxide dissolution as reaction temperature increased.

It is expected that higher olivine to carbonate conversion is achieved with increased pressure of carbon dioxide (Santos et al, 2016, pp.1-6). From his experiment, the conversion rate is almost doubled (from $8 \%$ to $16 \%$ ) when the total pressure was doubled from 60 to 120 bar after 3 hours of reaction time. The reason behind it was that a higher carbonic acid concentration improved mineral dissolution and, at the same time, promoted carbonate precipitation.

The liquid to solid ratio L/S represents the weight ratio of water to solid in aqueous carbonation slurry. The optimal proposed L/S ratio was $10 \mathrm{~mL} / \mathrm{g}$ (Rahmani et al, 2014, pp.5953-5958). Although a high L/S ratio 
was advantageous for decreasing water treatment and saving energy during dehydration, additional water is required to extract calcium and magnesium in the indirect carbonation process. The reduction of the L/S ratio also has small contribution to the overall conversion rate, which suggested it could result in more calcium and magnesium ions in the solution and, therefore, stronger ionic strength.

As the L/S ratio increased, the carbonation rate also increased because aqueous carbonation was dominant (Chang et al, 2012, pp.97106). As the L/S increased more, however, the conversions did not increase because the excess amount of the aqueous medium formed a mass transfer barrier, and, as a result, the ionic strength was lower. There was a limit to the liquid to solid ratio between $10-20 \mathrm{~mL} / \mathrm{g}$ for the carbonation process because a large amount of water could limit the conversion rate. Dunite carbonation in a batch-tubular reactor was performed with an increased S/L ratio of $2.8 \mathrm{~g} / \mathrm{ml}$ (Agrawal \& Mehra, 2020). The results revealed the precipitation of magnesite under diffusion limited conditions. The $\mathrm{SiO}_{2}$ formation and magnesite precipitation fill the pore space and the fractured zone on the rock surface.

The positive role of the added $\mathrm{NaHCO}_{3}$ in olivine carbonation was confirmed, but not investigated in detail (Stopic et al, 2018, pp.193-207). The synthesis of magnesium carbonate was studied using olivine under a partial pressure of carbon dioxide higher than 100 bar at $175^{\circ} \mathrm{C}$. The combination of organic acids such as oxalic acid and ascorbic acid accelerates the carbonation of olivine, reducing the formation of the silicate passive layer (Stopic et al, 2019, pp.135-147). The synthesis of nanosilica was studied via olivine carbonation using the size fraction between 20 and $63 \mu \mathrm{m}$ with the solid/liquid ratios of $1: 10$ at $175^{\circ} \mathrm{C}$ and a partial pressure of $\mathrm{CO}_{2}$ higher than 100 bar in an autoclave in the presence of additives such as sodium bicarbonate, and oxalic and ascorbic acid. Under the above-mentioned conditions, ideally spherical particles of silica below $500 \mathrm{~nm}$ with amorphous grains were produced during carbonation. An increase in stirring speed from $600 \mathrm{rpm}$ to 1800 rpm in an autoclave leads to the increased formation of magnesium carbonate and silica. An increased stirring speed has a positive influence on the separation of the formed silica-rich layer of the non-reacted magnesium silicate. On the other hand, the pressure in an autoclave was increased from 120 to 170 bar with an increasing stirring speed from 600 to $1800 \mathrm{rpm}$, which is an additional support for the silica separation and precipitation from the solution. The use of strong turbulence for better mixing of reactants to avoid the formation of a silica passivation layer was mostly studied in literature (Stockmann et al, 2014, pp.31439- 
31445). Using a strong mixing device, such as a high gravity rotary reactor, might also help to resolve this issue.

A new mechanism model for metal extraction (nickel, iron, magnesium) from olivine-bearing ore by avoiding silica gel formation during leaching with hydrochloric acid including a carbonation pretreatment was proposed (Matus et al, 2020, pp.811-827). This study explains additionally the behavior of metals such as nickel, magnesium, and iron during the carbonation of olivine-bearing ore and the leaching of a carbonated solid product.

In accordance with the previously mentioned analysis of the reaction parameters, an experiment was designed in order to reach maximum carbonation efficiency. This paper will explain the carbonation of olivine and the carbonation of slag under chosen experimental conditions. A comparison of their carbonation efficiencies will be mentioned in order to choose the most suitable material for scale up experiments.

\section{Experimental}

\section{Material}

The samples of olivine (Norway), ladle slag, and electric arc furnace slag (Germany) were studied for carbonation in water solution under high pressure conditions in an autoclave. It should be noted that, despite different particle sizes, the results of the XRF analysis are very similar in the case of different olivine Steinsvik. The characterization was performed by the X-ray fluorescence (XRF) technique, type PW2404 (Malvern PANalytical, Malvern, UK). Milling was performed using a Roller Mill, Type LWBP 2/2 (Karl Merz Maschinenfabrik GmbH, 1972 (year of manufacture), Heschingen, Germany). Sieving was performed using a Sieving Maschine, Type Prüf 86 (Siebtechnik $\mathrm{GmbH}$, Mühlheim an der Ruhr, Germany). In the case of slag, all tests were run with a particle size $<63 \mu \mathrm{m}$, since a slag particle size analysis was not part of this work. The presence of calcium oxide and magnesium oxide is the most important parameter for the carbonation process. Because of different behaviors of metal silicate and metal oxide through carbonation, the mineralogical composition mostly influences high carbonation efficiency. The maximum content of calcium oxide and magnesium oxide in electric arc furnace (EAF) slag amounts to $55.90 \%$, in contrast to its minimum presence found in mineral olivine $(43.67 \%)$. Because of this situation, the maximum carbonation value was expected for EAF and the minimum carbonation value for olivine. Besides the chemical compositions of the studied samples, the particle size and the active surface area have an 
important role in a higher carbonation level. A higher amount of silicon in the sample can be later included in a newly formed passive layer as a barrier for the carbonation process in an autoclave. Some part of iron can also be carbonated. Aluminium and manganese are not included in the carbonation process.

Table 1 - Chemical compositions of the samples used in the carbonation process Таблица 1 - Химический состав образцов, используемых в процессе карбонизации Табела 1 - Хемијски састав узорака који се користе у процесу карбонизације

\begin{tabular}{|l|l|l|l|l|l|l|l|}
\hline \multirow{2}{*}{ Sample } & \multicolumn{6}{l}{ Chemical composition (\%) } \\
\cline { 2 - 8 } & $\mathrm{NiO}$ & $\mathrm{MgO}$ & $\mathrm{CaO}$ & $\mathrm{Fe}_{2} \mathrm{O}_{3}$ & $\mathrm{Al}_{2} \mathrm{O}_{3}$ & $\mathrm{SiO}_{2}$ & $\mathrm{MnO}$ \\
\hline $\begin{array}{l}\text { Olivine- } \\
\text { Steinsvik }\end{array}$ & 0.4 & 43.45 & 0.24 & 7.41 & 0.51 & 47.34 & 0.11 \\
\hline Ladle Slag & - & 5.19 & 42.45 & 12.45 & 27.56 & 7.65 & 2.69 \\
\hline $\begin{array}{l}\text { Electric arc } \\
\text { furnace slag }\end{array}$ & - & 11.17 & 44.83 & 0.12 & 6.36 & 32 & 0.19 \\
\hline Wollastonite & - & 1.52 & 45.42 & 0.41 & 0.13 & 52.56 & 0.19 \\
\hline
\end{tabular}

The used samples are shown in Figure 1:

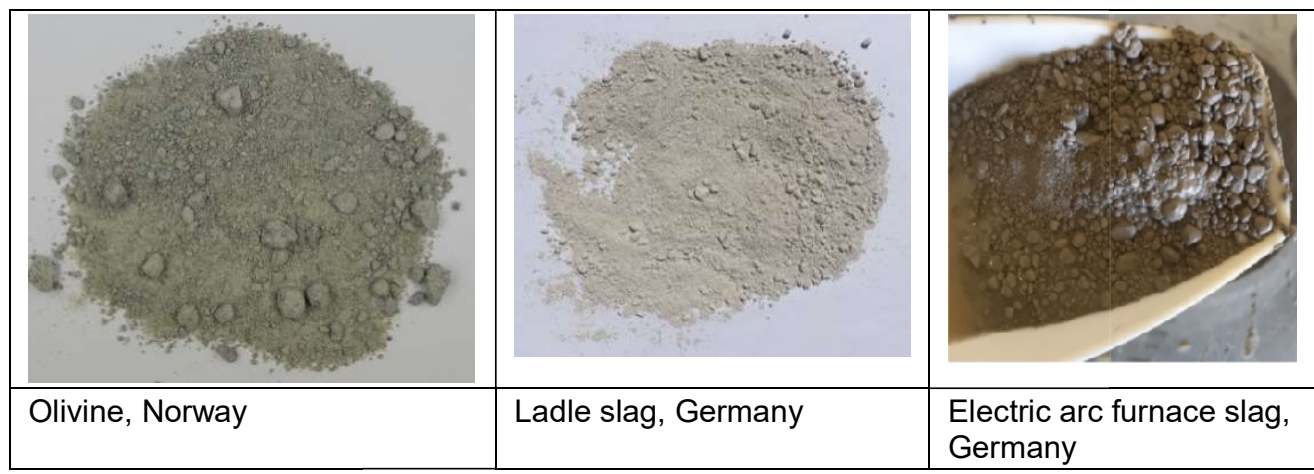

Figure 1 - The used samples in the carbonation process

Puc. 1 - Используемые образцы в процессе карбонизации Слика 1 - Коришћени узорци у процесу везивања угљен-диоксида

\section{Procedure}

The treatment of olivine first included the operations such as milling, sieving, and carbonation under high pressure conditions with an additional filtration and a chemical analysis of solid and liquid. The carbonation tests were carried out in a $9.9 \mathrm{~L}$ autoclave (Hastelloy C22 pressure reactor) of a kiloclave Type 3E (Büchi, Switzerland) with electric 
heating and water cooling (as shown in Figure 2) at $175^{\circ} \mathrm{C}$ with 71.5 bar pure grade $\mathrm{CO}_{2}$ in the presence of additives such as sodium bicarbonate, oxalic acid, and ascorbic acid. The planned experiments in this work will show how the the previously mentioned results from the experiments performed in the $0.25 \mathrm{~L}$ and $1.0 \mathrm{~L}$ autoclave relate to the $10 \mathrm{~L}$ autoclave experiment and validate the obtained results.

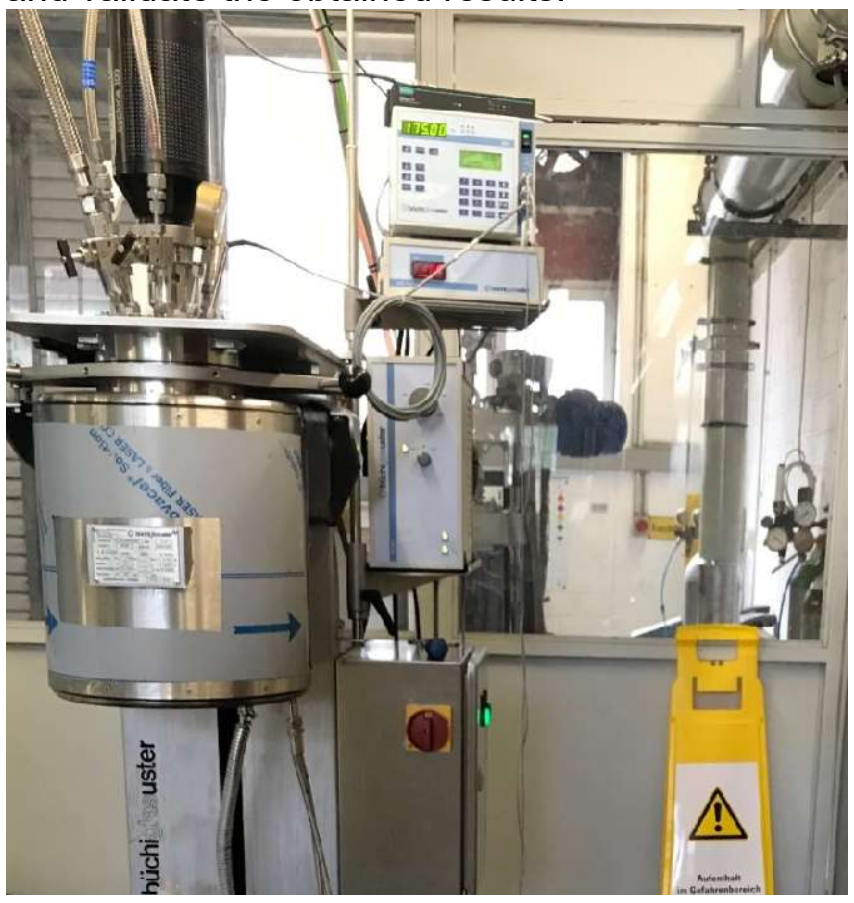

Figure 2 - Autoclave for the carbonation process

Puc. 2 - Автоклав для процесса карбонизации

Слика 2 - Аутоклав за везивање угљен-диоксида

For the carbonation of samples, the stabilization initial pressure is of great importance. The stabilization pressure is the pressure set at the beginning of the experiment by $\mathrm{CO}_{2}$ injection. This pressure was set at room temperature. The adjustment was made by continuously adding gas until the pressure stabilized in the system. Since there is reduction in the pressure in the system during gas introduction due to the chemical reaction of $\mathrm{CO}_{2}$ with water, it is important to perform stabilization. In this regard, it was observed that the higher the stabilization, the higher carbonation levels were obtained. However, this also depended on the grain size and the returned liquid. The Büchi software, Switzerland, was 
used for the analysis of pressure, temperature, and stirring speed in an autoclave.

\section{Reaction parameters}

In the carbonation tests, the increase of the carbonation degree by changing the influencing parameters was investigated. Some parameters were kept constant as they were found to be suitable according to the previously mentioned literature. In the case of the tests with olivine ore, the solid/liquid ratio and the stirring speed were kept constant.

The following listed carbonation parameters are shown in Table 2.

Table 2 - List of the reaction parameters (Additives: $0.64 \mathrm{M}$ sodium bicarbonate, $0.04 \mathrm{M}$ oxalic acid \& $0.01 \mathrm{M}$ ascorbic acid, $600 \mathrm{rpm}$, solid/Liquid= $1 \mathrm{~kg} / 8 \mathrm{~L}$ )

Таблица 2 - Список реакционных параметров (добавки: 0,64 М бикарбонат натрия, 0,04 М щавелевая кислота и 0,01 М аскорбиновая кислота, 600 оборотов в минуту, соотношение твердое вещество / жидкость = 1 ка / 8 л)

Табела 2 - Листа реакционих параметара (додаци: 0,64 М натријум-карбоната, 0,04 М оксалне киселине и 0,01 М аскорбинске киселине, при 600 обртаја у минути и односу чврстог материјала и раствора $1 \mathrm{~kg} / 8 \mathrm{l})$

\begin{tabular}{|l|l|l|l|l|l|}
\hline Material & $\begin{array}{l}\text { Particle } \\
\text { size }(\mu \mathrm{m})\end{array}$ & $\begin{array}{l}\text { Initial } \\
\text { stabilizing } \\
\text { pressure } \\
(\mathrm{bar})\end{array}$ & $\begin{array}{l}\text { Max. } \\
\text { Pressure } \\
(\text { bar })\end{array}$ & $\begin{array}{l}\text { Time } \\
(\text { hours })\end{array}$ & $\begin{array}{l}\text { Temperature } \\
\left({ }^{\circ} \mathrm{C}\right)\end{array}$ \\
\hline Olivine & $\begin{array}{l}<11,<20, \\
20-63, \\
<63\end{array}$ & $15-30$ & $40-80$ & $2-4$ & 100,175 \\
\hline $\begin{array}{l}\text { Ladle Slag, } \\
\text { EAF-slag, } \\
\text { wollastonite }\end{array}$ & $<63$ & $15-20$ & 50 & 4 & 100,175 \\
\hline
\end{tabular}

By calculating the degree of carbonation, it is possible to determine the maximum $\mathrm{CO}_{2}$ absorption capacity of the feedstock. It must be taken into account that not all of the studied material is capable of absorbing $\mathrm{CO}_{2}$. Therefore, only the proportion of $\mathrm{MgO}$ is considered for olivine and the proportion of $\mathrm{MgO}$ and $\mathrm{CaO}$ for slag. The loss on ignition gives a global estimate of the experiment efficiency, since the higher the loss on ignition, the more $\mathrm{CO}_{2}$ was absorbed in percentage terms.

The particle size plays a decisive role in the success of olivine carbonation. The smaller the particle size, the higher the degree of carbonation achieved (as shown in Figure 3). The carbonation reaction of magnesium silicate from olivine was presented with Equation 1: 


$$
\mathrm{Mg}_{2} \mathrm{SiO}_{4}+2 \mathrm{CO}_{2} \rightarrow 2 \mathrm{MgCO}_{3}+\mathrm{SiO}_{2}
$$

An increase in pressure of carbon dioxide increases carbonation efficiency. The maximum carbonation efficiency of olivine at $175{ }^{\circ} \mathrm{C}$ amounts to $70 \mathrm{~kg} \mathrm{CO}_{2} / \mathrm{ton}$.

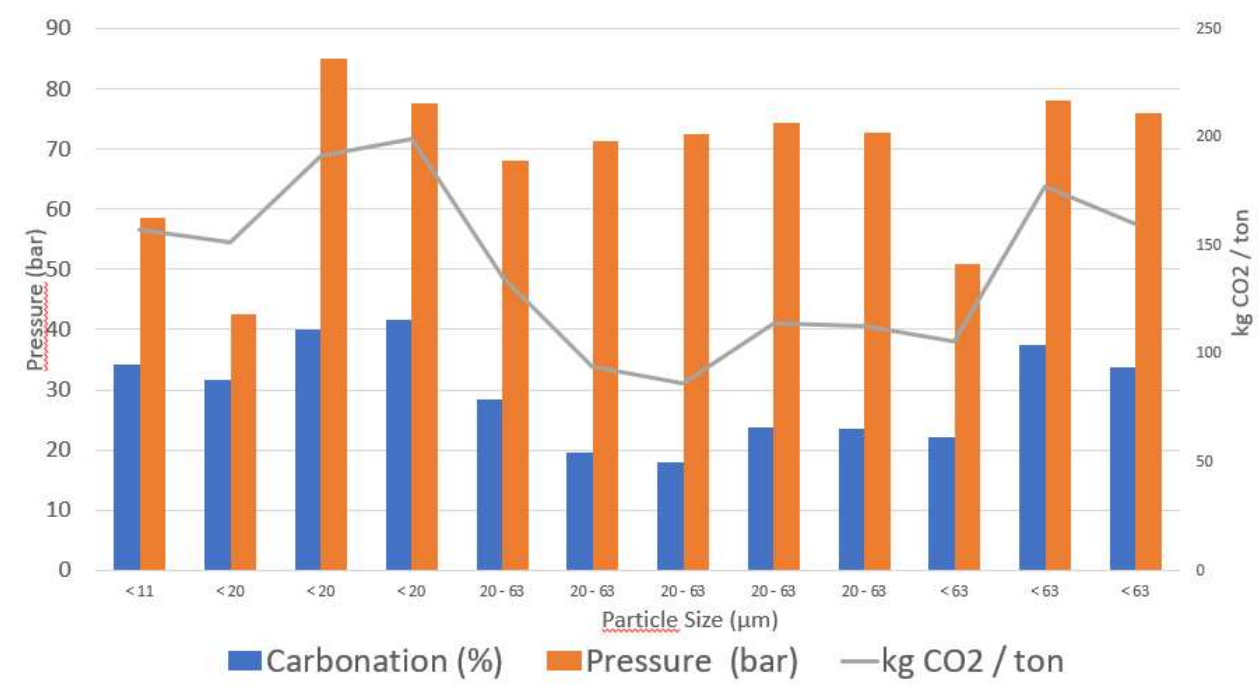

Figure 3 - Degrees of carbonation for different particle sizes of olivine in the presence of additives at $175^{\circ} \mathrm{C}, 600 \mathrm{rpm}, \mathrm{S} / \mathrm{L}=1 / 8$

Puc. 3 - Степень карбонизации при различной величине частиц оливина с добавками при $175^{\circ} \mathrm{C}, 600$ оборотов в минуту, соотношение твердое вещество / жидкость = 1 ке / 8 л)

Слика 3 - Степени везивања угљен-диоксида за различите величине честица оливина у присуству додатака на $175^{\circ} \mathrm{C}$, при 600 обртаја у минути и односу чврстог материјала и раствора 1:8

The result of the test with a decreased particle size smaller than 11 $\mu \mathrm{m}$ is different from the expected value. Here, the carbonation degree was $34.28 \%$ despite an extremely small particle size. This raises a possibility that there is a critical particle size between $0-20 \mu \mathrm{m}$ above which further grinding of olivine is no longer worthwhile. The carbonation of slags and wollastonite was performed in the presence and absence of additives, as shown in Figure 4. 


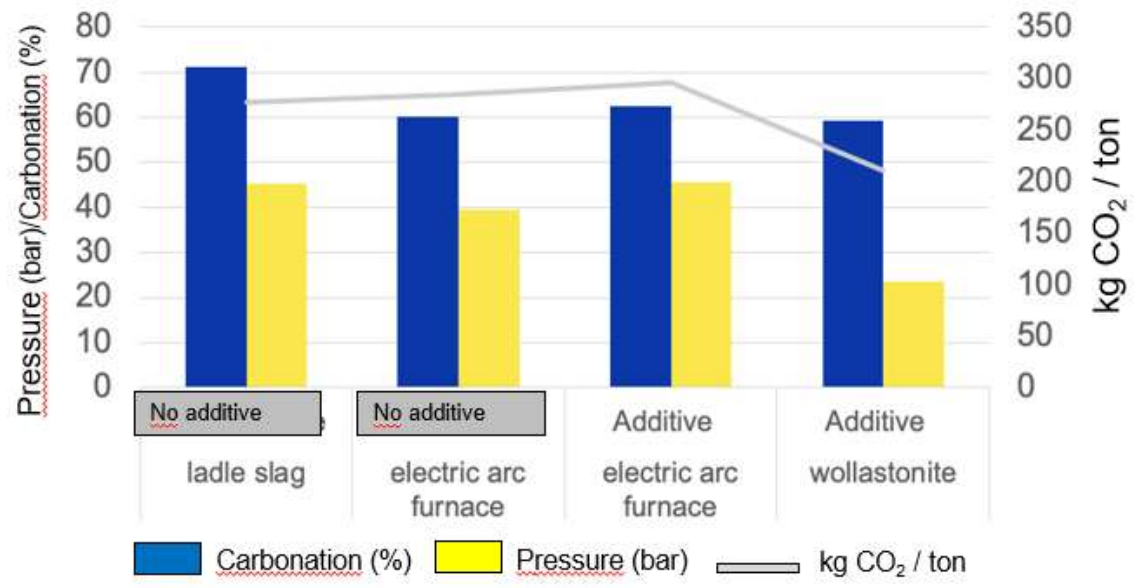

Figure 4 - Degrees of carbonation for different types of slags at $175^{\circ} \mathrm{C}, 600 \mathrm{rpm}, \mathrm{S} / \mathrm{L}=1 / 8$ Puc. 4 - Степень карбонизации для различных видов шлаков при $175^{\circ} \mathrm{C}, 600$ оборотов в минуту, соотношение твердое вещество / жидкость = 1 ка / 8 л) Слика 4 - Степени везивања уәљен-диоксида за различите типове шљака на $175^{\circ} \mathrm{C}$,при 600 обртаја у минути и односу чврстог материјала и раствора 1/8

After a confirmation that EAF slag is suitable for carbonation, it was investigated whether the addition of additives affects the degree of carbonation. As shown in Figure 4, the carbonation degree of EAF slag both without additives and in the presence of additives amounts to $60.13 \%$, which confirms no influence and significance of their using in slag carbonation. This result was confirmed in the case of wollastonite carbonation.

$$
\mathrm{CaSiO}_{3}+\mathrm{CO}_{2}=\mathrm{CaCO}_{3}+\mathrm{SiO}_{2}
$$

The maximum carbonation efficiency was obtained for ladle slag (about $70 \%$ or $300 \mathrm{~kg} \mathrm{CO} /$ ton) at $175{ }^{\circ} \mathrm{C}$ in the absence of additives. However, only one test was run with this slag because solids cemented to the bottom of the reactor and the cleaning of the reactor was very difficult. To free the carbonated ladle slag from the reactor, a two-hour leaching process at $100^{\circ} \mathrm{C}$ with acetic acid was necessary.

In the case of electric arc furnace slag (EAF slag), the degree of carbonation is somewhat lower than for ladle slag. However, no cementation problems were encountered with EAF slag, making this slag suitable for the carbonation test. The disadvantage of EAF slag is the 
formation of small stones during the carbonation tests. This caused some problems during the subsequent filtration process.

\section{Conclusion}

Carbonation of minerals and slag in an autoclave seems to be a prominent solution to the problem of rising carbon dioxide levels in the air. Carbonation of olivine and slag was successfully performed at $175^{\circ} \mathrm{C}$ under high pressure conditions (40-80 bar) in a $10 \mathrm{~L}$ autoclave. A comparative analysis has confirmed better carbonation of slag (max. 300 $\mathrm{kg} \mathrm{CO}_{2}$ /ton) in comparison to that of olivine (max. $70 \mathrm{~kg} \mathrm{CO}_{2} /$ ton) under the same conditions. The presence of additives such as sodium bicarbonate and oxalic and ascorbic acid is very important for olivine carbonation, but without influence in the case of slag, which is very important regarding an efficient cost-effectiveness analysis.

One challenge of mineral carbonation is to make it economically feasible. The obtained results will help to design future mineral carbonation experiments in scale up conditions.

\section{References}

Agrawal, A.K. \& Mehra, A. 2020. Dunite carbonation in batch-tubular reactor. Environmental Science and Pollution Research, 27, pp.31439-31445. Available at: https://doi.org/10.1007/s11356-020-09426-4.

Chang, E-E., Pan, S-Y., Chen, Y-H., Tan, C-S. \& Chiang, P-C. 2012. Accelerated carbonation of steelmaking slags in a high-gravity rotating packed bed. Journal of Hazardous Materials, 227-228, pp.97-106. Available at: https://doi.org/10.1016/j.jhazmat.2012.05.021.

Chang, E-E., Pan, S-Y., Chen, Y-H, Chu, H-W., Wang, C-F. \& Chiang, PC. 2011. $\mathrm{CO}_{2}$ sequestration by carbonation of steelmaking slags in an autoclave reactor. Journal of Hazardous Materials, 195, pp.107-114. Available at: https://doi.org/10.1016/j.jhazmat.2011.08.006.

Gadikota, G., Matter, J., Kelemen, P. \& Park, A-h.A. 2014. Chemical and morphological changes during olivine carbonation for $\mathrm{CO}_{2}$ storage in the presence of $\mathrm{NaCl}$ and $\mathrm{NaHCO}_{3}$. Physical Chemistry Chemical Physics, 16(10), pp.4679-4693. Available at: https://doi.org/10.1039/C3CP54903H.

Matus, C., Stopic, S., Etzold, S., Kremer, D., Wotruba, H., Dertmann, C., Telle, R., Friedrich, B. \& Knops, P. 2020. Mechanism of Nickel, Magnesium, and Iron Recovery from Olivine Bearing Ore during Leaching with Hydrochloric Acid Including a Carbonation Pre-Treatment. Metals, 10(6), art.number:811, pp.811827. Available at: https://doi.org/10.3390/met10060811. 
Rahmani, O., Junin, R., Tyrer, M. \& Mohsin, R. 2014. Mineral carbonation of red gypsum for $\mathrm{CO}_{2}$ sequestration. Energy \& Fuels, 28(9), art.number:708. Available at: https://doi.org/10.1021/ef501265z.

Santos, R.M., Knops, P.C.M., Rijnsburger, K.L. \& Chiang, Y.W. 2016. CO2 energy reactor-integrated mineral carbonation: perspectives on lab-scale investigation and products valorization. Frontiers in Energy Research, 4(art.number:5), pp.1-6. Available at: https://doi.org/10.3389/fenrg.2016.00005.

Stockmann, G.J., Wolff-Boenisch, D., Bovet, N., Gisslason, S.R., Oelkers, E.H. 2014. The role of silicate surfaces on calcite precipitation kinetics. Geochimica et Cosmochimica Acta, 135, pp.231-250. Available at: https://doi.org/10.1016/j.gca.2014.03.015.

Stopic, S., Dertmann, C., Koiwa, I., Kremer, D., Wotruba, H., Etzold, S. Telle, R., Knops, P. \& Friedrich, B. 2019. Synthesis of Nanosilica via Olivine Mineral Carbonation under High Pressure in an Autoclave. Metals, 9(6), art.number:708, pp.135-147. Available at: https://doi.org/10.3390/met9060708.

Stopic, S., Dertmann, C., Modolo, G., Kegler, P., Neumeier, S., Kremer, D., Wotruba, H., Etzold, S., Telle, R., Rosani, D., Knops, P. \& Friedrich, B. 2018. Synthesis of Magnesium Carbonate via Carbonation under High Pressure in an Autoclave. Metals, 8(12), art.number:993, pp.193-207. Available at: https://doi.org/10.3390/met8120993.

\section{КАРБОНИЗАЦИЯ МИНЕРАЛОВ И ШЛАКОВ ПОД ВЫСОКИМ} ДАВЛЕНИЕМ В АВТОКЛАВЕ

Карлос Ф. Матус ${ }^{\text {, }}$ Сречко Р. Стопич ${ }^{\sigma}$, корреспондент, Бернд Г. Фридрих ${ }^{б}$

${ }^{a}$ Refratechnik Cement $\mathrm{GmbH}$,

г.Геттинген, Федеративная Республика Германия

б Технический университет города Ахен,

Институт металлургических процессов и рециклирования металлов,

г. Ахен, Федеративная Республика Германия

РУБРИКА ГРНТИ: 61.00.00 ХИМИЧЕСКАЯ ТЕХНОЛОГИЯ. ХИМИЧЕСКАЯ ПРОМЫШЛЕННОСТЬ:

61.13.21 Химические процессы

ВИД СТАТЬИ: оригинальная научная статья

Резюме:

Введение/цель: Карбонизация минералов (оливина и волластонита) и вторичных материалов под высоким давлением в автоклавах очень важно для охраны окружающей среды. 
Методы: Наиболее важным в данном процессе является познание того, как себя ведет диоксид углерода в водном растворе под высоким давлением, как происходит растворение металлов таких как никель и магний, а также их последующая фрильтрация.

Результаты: Процесс карбонизации оливина и шлака под высоким давлением (от 40 до 80 бар) был успешно проведен при $175{ }^{\circ} \mathrm{C}$ в автоклаве с добавками и без них.

Выводы: Сравнительный анализ показал, что карбонизация шлака (макс. 300 кг $/ \mathrm{m}$ ) по сравнению с карбонизацией оливина (макс.70 ке/ m) в одинаковых условиях производится намного лучше.

Ключевые слова: карбонизация, оливин, шлак, автоклав, добавки.

\section{ВЕЗИВАЊЕ УГЉЕН-ДИОКСИДА СА МИНЕРАЛИМА И ШЉАКОМ ПРИ ВИСОКОМ ПРИТИСКУ У АУТОКЛАВУ}

Карлос Ф. Матус ${ }^{\mathrm{a}}$, Срећко Р. Стопић ${ }^{\sigma}$, аутор за преписку,

Бернд Г. Фридрих

${ }^{a}$ Refratechnik Cement GmbH, Гетинген, Савезна Република Немачка

б Технички универзитет у Ахену, Институт за процесну металургију и рециклирање метала, Ахен, Савезна Република Немачка

ОБЛАСТ: хемијске технологије

ВРСТА ЧЛАНКА: оригинални научни рад

Сажетак:

Увод/циљ: Везивање угљен-диоксида са минералима (оливин и воластонит) и секундарним материјалима при високом притиску у аутоклаву врло је важно за заштиту животне средине.

Методе: За овај процес најважније је понашање угљен-диоксида у воденом раствору при високом притиску и растварање метала као што су никал и магнезијум, као и наредна филтрација.

Резултати: Процес везивања угљен-диоксида са оливином и шљаком успешно је изведен у аутоклаву на $175^{\circ} \mathrm{C}$ између 40 и 80 бара у присуству и одсуству адитива.

Закључак: Упоредна анализа је потврдила боље везивање уәљендиоксида са шљаком (максимално $300 \mathrm{~kg} / \mathrm{t}$ ) у поређењу са оливином (максимално $70 \mathrm{~kg} / \mathrm{t}$ ) при истим условима.

Кључне речи: везивање угљен-диоксида, оливин, шљака, аутоклав, додаци. 
Paper received on / Дата получения работы / Датум пријема чланка: 07.01.2021 Manuscript corrections submitted on / Дата получения исправленной версии работы / Датум достављања исправки рукописа: 01.03.2021.

Paper accepted for publishing on / Дата окончательного согласования работы / Датум коначног прихватања чланка за објављивање: 03.03.2021.

(c) 2021 The Authors. Published by Vojnotehnički glasnik / Military Technical Courier

(www.vtg.mod.gov.rs, втг.мо.упр.срб). This article is an open access article distributed under the terms and conditions of the Creative Commons Attribution license (http://creativecommons.org/licenses/by/3.0/rs/).

() 2021 Авторы. Опубликовано в «Военно-технический вестник / Vojnotehnički glasnik / Military Technical Courier» (www.vtg.mod.gov.rs, втг.мо.упр.срб). Данная статья в открытом доступе и распространяется в соответствии с лицензией «Creative Commons» (http://creativecommons.org/licenses/by/3.0/rs/).

( 2021 Аутори. Објавио Војнотехнички гласник / Vojnotehnički glasnik / Military Technical Courier (www.vtg.mod.gov.rs, втг.мо.упр.срб). Ово је чланак отвореног приступа и дистрибуира се у складу са Creative Commons licencom (http://creativecommons.org/licenses/by/3.0/rs/).

(c) (i) 